\title{
Centrality of the Ranching Lifestyle and Attitudes Toward a Voluntary Incentive Program to Protect Endangered Species
}

\author{
Michael G. Sorice, ${ }^{1}$ J. Richard Conner, ${ }^{2}$ Urs P. Kreuter, ${ }^{3}$ and R. Neal Wilkins ${ }^{4,5}$ \\ Authors are ${ }^{1}$ Assistant Professor, Department of Forest Resources \& Environmental Conservation, Virginia Tech, Blacksburg, VA 24061, USA; \\ ${ }^{2}$ Professor, Department of Agricultural Economics, Texas AઐM University, College Station, TX 77843, USA; ${ }^{3}$ Professor, Department of Ecosystem \\ Science \& Management, Texas A\&M University, College Station, TX 77843, USA; ${ }^{4}$ Director, Institute of Renewable Natural Resources, Texas A\&M \\ University, College Station, TX 77843, USA; and ${ }^{5}$ Professor, Department of Wildlife and Fisheries Sciences, Texas Agricultural Experiment Station, Texas \\ Cooperative Extension, Texas A※M University, College Station, TX 77843, USA.
}

\begin{abstract}
The Endangered Species Act of 1973 has served as the defacto biodiversity policy in the United States; however, heavy-handed implementation early in the act's history led private landowners to avoid managing land to benefit endangered species. By reducing costs and increasing benefits to landowners, voluntary incentive programs (VIPs) potentially bridge the gap between a policy that discourages beneficial land management on private lands and the need to enhance recovery efforts. However, the effectiveness of VIPs is bound to landowner participation. With the use of a sample of rangeland landowners in central Texas, we examined the potential for private landowners to enroll in an incentive program to protect and maintain habitat for endangered songbirds. First, we characterized landowners based on the centrality of production-oriented agriculture to their lifestyle. This measure of lifestyle centrality was comprised of self-identification as a rancher/farmer, dependence on land for income, and rootedness to the land. Second, we examined the relationship between lifestyle centrality, attitude, and participation in a VIP. With the use of structural-equation modeling, we found attitude toward enrolling mediated the relationship between centrality and a landowner's intention to enroll in a VIP. In addition to demographic analyses, social variables such as attitudes, beliefs, and motivations are needed to understand fully the multiple underlying reasons for participation and nonparticipation in a VIP and to design effective interventions to enhance participation.
\end{abstract}

\section{Resumen}

La ley de especies en peligro de extinción de 1973 ha servido como la política en práctica de la biodiversidad en los Estados Unidos; sin embargo, la aplicación al inicio de la ley llevó a productores privados a evitar que el manejo de la tierra beneficiara a las especies en peligro de extinción. Reduciendo los costos y aumentando los beneficios para los propietarios de las tierras el programa de incentivo voluntario (VIPs) posiblemente abre una posibilidad entre una política que desalienta los beneficios del manejo de la tierra en la propiedad privada y la necesidad de intensificar los esfuerzos de recuperación. Sin embargo, la efectividad de los VIPs está vinculada con la participación de los propietarios. Utilizando una muestra de los propietarios de pastizales en la parte central de Texas se examinó la posibilidad de que los propietarios privados se inscribieran en un programa de incentivos para proteger y mantener el hábitat para aves canoras en peligro de extinción. Primero, se caracterizó a los productores basándose en la centralidad de la agricultura orientada a la producción y a su estilo de vida. Esta medida de centralidad del estilo de vida se basó en auto identificación como ganadero y/o agricultor, la dependencia de la tierra para sus ingresos así como el arraigo a la tierra. Segundo, se examinó la relación entre la centralidad del estilo de vida, la actitud y la participación en un VIP. Por medio del modelado de ecuaciones estructurales, nos enfocamos en actitud para registrarse por la relación entre la centralidad y la intención del propietario de inscribirse en un VIP. Además de los análisis demográficos, las variables sociales como las actitudes, creencias y motivaciones se necesitan para entender las razones múltiples detrás de la participación y no participación en un VIP y permiten diseñar intervenciones eficaces para mejorar la participación.

Key Words: attitudes, cost-share programs, financial dependence, private lands, rootedness, self-identity, sense of place, structural-equation modeling, working lands

\section{INTRODUCTION}

Research was funded by the Dept of Defense, Office of the Secretary of Defense and further supported by the Institute of Renewable Natural Resources, Texas A\&M University.

At the time of data collection, Sorice was a PhD candidate, Dept of Wildlife \& Fisheries Sciences, Texas A\&M University, College Station, TX 77843, USA.

Correspondence: Michael G. Sorice, Dept of Forest Resources \& Environmental Conservation, Virginia Tech, 310A Cheatham Hall (0324), Blacksburg, VA 24061, USA. Email: msorice@ vt.edu

Manuscript received 10 September 2010; manuscript accepted 29 September 2011.
Rangeland ecosystems provide a wealth of ecosystem services. Biodiversity enhances ecosystem services (e.g., regulating services) and can be an ecosystem service itself (e.g., cultural services), which can lead to increased human well-being (Millennium Ecosystem Assessment 2003). Thus, maintaining or enhancing biodiversity in rangeland ecosystems is a desired social goal. Conservation of biodiversity in rangelands is complex because most rangeland systems in the United States are working lands dominated by resource industries such as agriculture, and most are private lands (Lubowski et al. 2006). 
Since 1973, the Endangered Species Act (ESA) has been the de facto biodiversity policy in the United States, focusing on preserving species richness. However, the effectiveness of this policy on private lands has been questioned (Norris 2004). One consequence of the ESA's historical implementation is a social memory amongst landowners characterized by a fear of potential land-use restrictions and loss of property rights. Such negative perceptions have created a so-called perverse incentive that discourages landowners from cooperating in efforts to manage land for the benefit of threatened and endangered species (Bean 1998; Lueck and Michael 2003). In turn, this has resulted in reduced information about the affected species (Polasky and Doremus 1998; Brook et al. 2003) and impeded coordinated ecosystem management efforts.

Many suggestions have been made to address the equity, fairness, and trust issues that lead private landowners to disengage from endangered species recovery efforts (Hadlock and Beckwith 2002b). Pointing to successful agricultural incentive programs such as the Conservation Reserve Program, Bean (1998, p. 10707) takes a strong stance on this issue by saying that "without positive incentives, the [Endangered Species] Act's goals are unlikely to be achieved." Thompson (2006) agrees with Bean and adds that a focus on reserves to the exclusion of the surrounding working landscape (e.g., farms and ranches) increases the chances that recovery efforts will ultimately fail.

Voluntary incentive programs (VIPs) potentially bridge the gap between a policy that discourages beneficial land management on private lands and the need to enhance recovery efforts by providing a structural solution that reduces costs and increases benefits to landowners for cooperating. In this context an incentive is "any inducement specifically intended to motivate private landowners to conserve endangered species on their property" (Hadlock and Beckwith 2002a, p. 200). Incentives can be monetary, including direct financial assistance in the form of subsidies (e.g., cost-share programs), mitigation banking, tradable credits, or incentives based on tax reform (e.g., conservation easements) (Parkhurst and Shogren 2003). Nonmonetary incentives focus on reducing uncertainty; increasing land-based benefits to the landowner, such as assistance with range- or forestland management; and balancing power between landowners and the regulatory agency.

The efficacy of a VIP to aid endangered species recovery is inextricably bound to landowner participation. Consequently, much of the literature examining VIPs focuses on who enrolls and ways to increase enrollment. Landowners are deeply connected to their land, highly independent (Peterson and Horton 1995), have multiple motivations for land ownership (Bliss and Martin 1989; Koontz 2001), and generally operate their land because it's a way of life more than a profitable economic venture (Ryan et al. 2003; Sheridan 2007). In addition, shifts in landowner composition (i.e., demographics) may lead to changes in land use, land management preferences, and support for endangered species recovery. Changes in the western United States (Gosnell et al. 2006), including Texas (see Wilkins et al. 2003), are altering not only the biophysical landscape but also the social landscape (Reading et al. 1994; Kreuter et al. 2006). In rural Texas, where native rangelands are the largest land-use category, properties are increasingly being subdivided into smaller land holdings; the number of ranches and farms less than 40 hectares in size increased $22 \%$ from 1997 to 2007 (Wilkins et al. 2009). Consequently, the type of landowner managing (or not managing) rangelands in Texas may be changing (Cearly-Sanders 2005). As a result of this shift, the role agricultural production plays in a landowner's lifestyle may be related to attitudes toward endangered species and thus attitudes toward cooperating in endangered species recovery efforts. Characterizing landowners based on how central agricultural production is to their life may provide insight into potential channels for enhancing endangered species conservation using VIPs.

The purpose of this research was to examine the relationship between involvement in ranching or farming and participation in a VIP. Our first objective was to establish a measure of lifestyle centrality related to farming and ranching and to characterize landowners based on this measure. Centrality to lifestyle is related to the social-psychological concept of involvement, which reflects the degree to which people devote themselves to an activity. This motivation is related to personal relevance-the extent to which the activity is related to or engages an individual's self-concept, needs, goals, and values (Kyle et al. 2007). Our measures of lifestyle centrality were constructed from previous research in the study area that qualitatively assessed the extent to which landowners were farmers and ranchers (Cearly-Sanders 2005). Based on this work, lifestyle centrality included the strength with which a landowner identified him or herself as a rancher or farmer, the landowner's perceived level of dependence on the land for income, and the length of time a landowner has been operating his or her place.

Our second objective was to examine the extent to which lifestyle centrality may directly or indirectly relate to VIP participation via a landowner's attitude toward participation. In many fields, including natural resource management, there is ample empirical evidence that attitudes can account for, or mediate, the relationship between behavior and characteristics of an individual (Ajzen and Fishbein 2005). Examining the nature of this relationship is important not only for understanding VIP participation, but for designing interventions to enhance it. We used attitude theory to propose a model relating a landowner's intention to enroll in a VIP with characteristics of the landowner. Based on these objectives we examined the following three hypotheses for a VIP to protect and maintain endangered species habitat:

1. Attitude toward participating will mediate the relationship between farming/ranching lifestyle centrality and intention to enroll.

2. As farming/ranching centrality increases, attitude toward enrolling will become more negative.

3. Intention to enroll will increase as attitude toward enrolling becomes more positive.

\section{METHODS}

\section{Sampling}

Sample selection focused on landowners in a six-county region of Texas (Bell, Bosque, Coryell, Hamilton, Lampasas, and 
McLennan counties) who had potential breeding habitat for the black-capped vireo (Vireo atricapilla) and the golden-cheeked warbler (Dendroica chrysoparia). These are two federally listed endangered species that could benefit significantly from a habitat management program on private lands. We obtained landowner information from each county's tax appraisal districts and, because the golden-cheeked warbler has the most restrictive habitat, we used a GIS model created and validated by Jones (2006) to identify land parcels with a moderate to high probability of having habitat. We further restricted the sampling frame to landowners with at least 10 hectares, because this is considered to be the minimum area needed by a breeding pair (e.g., Anders and Dearborn 2004), and it is of interest given the current demographic trend in Texas land ownership toward smaller-sized properties (Wilkins et al. 2003). We submitted 1200 landowner names and addresses to a consumer information company to obtain available phone numbers. Our final sampling frame consisted of 542 landowners. We know of no literature suggesting that the attenuation in the sampling frame results in a biased sample.

We faced the challenge that endangered species issues are not salient for most landowners (e.g., Raymond and Olive 2008) and generally raise concerns about the potential for regulation. Given some poor response rates on this topic we felt that a trade-off of talking to landowners (to enhance response rate) was warranted over the sampling breadth that a mail survey may have provided. For example, although Zhang and Mehmood (2002) had a $65 \%$ response rate for a mail survey sent to landowners enrolled in the U.S. Fish and Wildlife Service's Safe Harbor program, questionnaires sent to landowners not enrolled in the program resulted in only a $17 \%$ response rate.

Accordingly, we adapted our research protocol to ease landowners into providing their views on endangered species. First, we sent a letter to the landowners advising them that we would be calling regarding a project on wildlife conservation. For landowners who agreed to participate, a face-to-face structured interview was conducted focusing on land-use and landowner characteristics. All interviews were conducted by the first author and two assistants trained by the first author. At the end of the 15-min interview, a self-administered questionnaire containing the VIP items was left with the participant along with a thank-you gift, a small watercolor print of a local landscape. To ensure a suitable response rate for the self-administered questionnaire we used a rolling reminder procedure adapted from the Dillman (2000) mail survey technique. One week after the interview we sent a thank-you/ reminder postcard followed 3 and 7 wk later by a reminder letter with a replacement questionnaire. Interviewing began in April 2007 and ended in November 2007.

\section{Data Collection}

Demographics. We collected a number of variables related to landowner characteristics including property ownership $(1=$ sole owner, $0=$ other), hectares managed (hectares owned + hectares leased in-hectares leased out), proportion of ranching experience (years of experience since age of 18/ [age -18$]$ ), years residing on property, previous enrollment in a cost-share program $(1=$ yes, $0=$ no), number of agency representatives spoken with in the past year, age, gender ( $1=$ male, $0=$ female), percent income generated from land $(1=0 \%, 2=1-9 \%, 3=10-24 \%, 4=25-49 \%, 5=50 \%$ or more), and annual income $(1=$ less than $\$ 100000$, $2=\$ 100000-199999,3=\$ 200000$ or more) .

Ranching Centrality. Lifestyle centrality focused on the degree to which a landowner believes that farming or ranching is a core part of his or her self-concept. This conceptualization is based largely on previous research and qualitative work in the same study area that presented a typology of landowners based on their connection to the land. Cearly-Sanders (2005) used the term born to the land to characterize landowners who are strongly attached to their land via their livelihood and the previous generations who operated it. This group comprises the "traditional" Texas rancher and contrasts with the reborn to the land group. The reborn group has an emotional and psychological connection to their land even though they may not have grown up or lived in a rural community for long. Although this group may operate livestock they do not necessarily engage in agricultural production as a profession and may own their land primarily for other reasons (e.g., aesthetics, recreation, etc.). Of these two groups in CearleySanders' (2005) study, the reborn group was more likely to indicate interest in enrolling in a VIP for endangered species. Based on this work, we conceptualized the centrality of the ranching lifestyle as a construct comprised of a landowner's identity as a farmer or rancher, their dependence on land for income, and their level of rootedness to the land (Fig. 1).

Identity. The centrality of ranching or farming to a landowner's lifestyle necessarily incorporates his or her identity. Identity is the set of meanings a person attaches to oneself and helps an individual distinguish oneself from and relate to others. Identity also serves as a guide to behavior because individuals generally seek to maintain their identity (Burke 1991). Thus, it potentially directly influences intentions and actions. Identity as a rancher consisted of three items measured on a 7-point scale from strongly disagree to strongly agree: (1) "Farming/ranching says a lot about who I am," (2) "I consider myself a rancher," and (3) "I consider myself a farmer."

Financial Dependence. A number of researchers have identified resource dependence as a factor that relates to conservation behavior and VIP participation. We operationalized resource dependence as the degree to which landowners rely on their land for income. We preferred this measure of dependence over the traditionally used measure of percent income derived from "activities on the land in the past year" because perceived dependence characterizes the way in which a landowner thinks about and approaches operating his or her land regardless of actual income. Furthermore, it should be a more stable measure than the traditional "percent income" measure because it implicitly incorporates income over time. Finally, the questions asked to construct perceived dependence are likely to have lower nonresponse rates than income-related questions. To understand financial dependence on the land, we asked landowners to respond to three items measured on a 7-point scale from strongly disagree to strongly agree: (1) "My place is an important source of income," (2) "My place is a business," and (3) "My place is a way to financially provide for my family." 


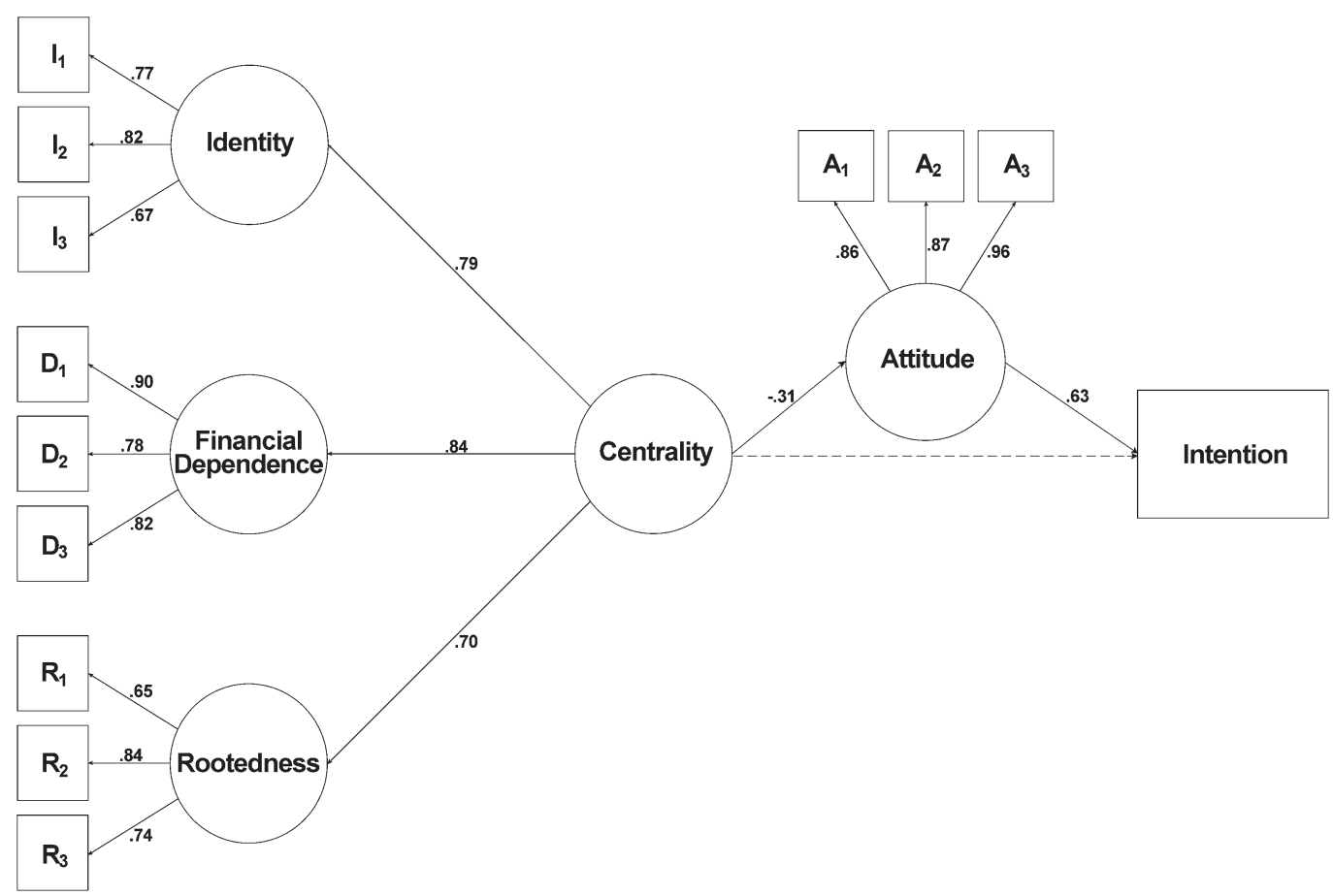

Figure 1. Structural-equation model showing the mediation model (dashed line indicates relationship tested in full model) relating lifestyle centrality (self-identity, financial dependence, and rootedness) to intention to enroll in a voluntary incentive program for 252 landowners in central Texas. Standardized coefficients are all statistically significant at $P<0.001$. Letters with subscripts correspond to items in Table 1.

Rootedness. At the most fundamental level rootedness is the length of time a landowner has lived on or owned their land. Tuan (1980, p. 5) further defines rootedness as "being completely at home-that is, unreflectively secure and comfortable in a particular locality." Tuan argues that rootedness is comprised of not only tenure but pride of one's own past in an area. Thus, in addition to an objective measure (time), it is also a psychological state of being. Rootedness is important in creating a sense of place and in shaping an individual's belief system. Brandenburg and Carroll (1995) argue that this sense of place can be important in understanding landowners' values and beliefs as they relate to land use. Our measure of rootedness included both a report of tenure and an assessment of pride about their past in the area: (1) "My place represents my family history," (2) "I am proud of my family's history on this place," and (3) "How many years has your place been in your family?" The first two items were measured with the use of a 7-point scale from strongly disagree to strongly agree, and the last was an open-ended question measured in years. Additionally, years the place has been in the family was log transformed to reduce skewness.

Attitude. Within the theory of reasoned action (Ajzen and Fishbein 1980; Fishbein and Ajzen 2010) the proximal cause of behavior is an individual's intention to engage in a behavior. Attitudes indirectly affect overt behavior by influencing this intention. Thus, there is a hierarchical relationship from the most general beliefs to the more specific behavior-related attitudes that increases one's ability to predict behavior (Homer and Kahle 1988). Within attitude theory, lifestyle centrality could be considered a background factor that is only indirectly related to behavior via attitude. However, some research has shown that constructs like self-identity uniquely contribute to the prediction of behavior (Eagly and Chaiken 1993, but see Fishbein and Azjen 2010). Given a lack of consensus on this issue, we expected attitude toward enrolling in a VIP to at least partially mediate the relationship between lifestyle centrality and a behavioral intention to participate in a VIP. We based our attitude measures on the Ajzen and Fishbein (1980) reasoned action approach and used Ajzen (2002) to guide construction of three attitude measures. Landowners evaluated enrolling on an instrumental level (extremely foolish to extremely wise), an experiential level (extremely undesirable to extremely desirable), and an overall evaluation (very bad to very good) with the use of a 7-point scale.

Intention. The program structure was based on a small rangeland restoration pilot project already implemented in the area; however, we did not refer to the project title and reframed it from an invasive-brush-clearing project to an endangered species protection program (incorporating brush control). Using a 7-point scale from extremely unlikely to extremely likely, landowners were asked about enrolling in the following program:

This program is run by a local nonprofit group in central Texas. Landowners volunteer for the program and enroll in a 5-yr performance contract to manage their land for two species of endangered birds. It provides $85 \%$ cost sharing to landowners to clear Ashe juniper, also called cedar, and to conduct a prescribed/controlled burn on a portion of their land. The contract also includes preserving some areas of mature oak-juniper woodlands on steep slopes and in canyons. The program provides assistance with the management plan and conducts the brush clearing and burn for the landowner. The benefits of this program include improved grazing capacity, ground and surface water conservation, and enhanced wildlife habitat. After the contract expires and the performance criteria are met, the landowners are reimbursed the 
remaining $15 \%$ of the costs (minus the costs for the prescribed burn) and are free to operate the land in whatever way they desire.

\section{Data Analysis}

We used descriptive statistics to characterize respondents with the use of demographic information. The reasoned action approach to understanding behavior has consistently demonstrated over many years and in many fields that background variables such as demographics do a poorer job of predicting behavioral intentions than social-psychological variables. Sorice (2008, Chapter 2) empirically verifies this for this data set; no statistically significant relationship was found between demographic variables and intention to enroll in the program examined here.

To understand the role of lifestyle centrality, we first examined the internal consistency of the latent constructs (identity, financial dependence, rootedness, and attitude) with the use of Cronbach's alpha and confirmatory factor analysis. Because the ranching centrality measurement model had not been previously employed, we assessed the validity and reliability of both the first- and second-order model (Hatcher 1994). We used a structural-equation path model to examine the mediating role of attitude toward enrolling. Two separate models were fitted with the use of AMOS 16.0 software (Arbuckle 2007). The partial-mediation model allowed for a direct effect between centrality and intention, whereas the fullmediation model did not. We assessed model fit with the use of multiple indicators including goodness of fit $\left(\chi^{2}\right)$, absolute fit (standardized root-mean-square residual [SRMR]), parsimony correction (root-mean-square error of approximation [RMSEA]), and comparative fit (comparative fit index [CFI]) (see Brown 2006, pp. 81-87 for details). We compared the partial and full mediation models with the use of the change in $\chi^{2}$ and the Akaike's information criterion (AIC). For all models, standardized regression coefficients are reported.

\section{RESULTS}

We obtained an interview cooperation rate of $56 \%$ for landowner interviews (based on American Association for Public Opinion Research 2006). Of the 303 self-administered questionnaires left with participants, 266 were returned for a self-administered survey response rate of $87 \%$ (based on Dillman 2000). Of these, 252 cases were usable in this analysis.

\section{Descriptive Statistics}

A large majority of respondents were sole owners (85\%), male $(87 \%)$, and indicated their race and ethnicity as white nonHispanic $(96 \%)$. One third of the respondents had completed a 4 -yr college degree or higher $(33 \%)$. The occupations reported for most respondents were not related to agricultural production $(86 \%)$ and $31 \%$ were retired or semiretired. The median income reported was $\$ 80,000$ to $\$ 99,999$ and the median percentage of that income derived from activities on the land was $2 \%$, with a mean of $12 \%$.

On average, respondents managed 143 hectares (standard deviation, $\mathrm{SD}=327$; median, $\mathrm{MD}=42.3$ ). Respondents who
Table 1. Mean responses and internal consistency of indicators of lifestyle centrality and attitude for 252 landowners in central Texas.

\begin{tabular}{|c|c|c|}
\hline Indicators $^{1}$ & Mean (SD) & $\alpha^{2}$ \\
\hline Identity & & 0.79 \\
\hline $\mathrm{I}_{1}$-Farming/ranching says a lot about who I am & $5.11(2.09)$ & \\
\hline $\mathrm{I}_{2}-\mathrm{I}$ consider myself a rancher & $4.47(2.22)$ & \\
\hline $\mathrm{I}_{3}-\mathrm{I}$ consider myself a farmer & $3.21(2.17)$ & \\
\hline Financial dependence & & 0.87 \\
\hline$D_{1}$-My place is an important source of income & $3.30(2.35)$ & \\
\hline $\mathrm{D}_{2}-$ My place is a business & $4.34(2.44)$ & \\
\hline $\begin{array}{l}\mathrm{D}_{3} \text { - My place is a way to financially provide for my } \\
\text { family }\end{array}$ & $3.36(2.32)$ & \\
\hline Rootedness & & 0.79 \\
\hline$R_{1}-$ Years place has been in your family & $41.87(37.86)$ & \\
\hline $\mathrm{R}_{2}-$ My place represents my family history & $4.56(2.48)$ & \\
\hline $\mathrm{R}_{3}-\mathrm{I}$ am proud of my family's history on this place & $5.70(1.81)$ & \\
\hline \multicolumn{3}{|l|}{ Attitude } \\
\hline$A_{1}$-Enrolling is undesirable or desirable & $4.89(1.92)$ & 0.92 \\
\hline $\mathrm{A}_{2}$-Enrolling is wise or foolish & $5.15(1.66)$ & \\
\hline $\mathrm{A}_{3}$-Enrolling is bad or good & $5.28(1.67)$ & \\
\hline
\end{tabular}

${ }^{1}$ Items scored on a 7-point scale where $1=$ strongly disagree and $7=$ strongly agree, except for years place has been in the family, which was measured in years. ${ }^{2}$ Cronbach's alpha.

leased out all of their land comprised $16 \%$ of the sample and $30 \%$ managed 40 hectares or less. Almost half of the respondents $(48 \%)$ managed their land for crops or livestock, whereas $32 \%$ focused on wildlife and $19 \%$ considered their place to be a residence, weekend getaway, or a tourism operation. On average, landowners had lived on their land for 14 yr $(S D=20 ; M D=5$; minimum $=0$; maximum $=92)$ but this was highly skewed, as $42 \%$ of landowners indicated they lived on their land for $0 \mathrm{yr}$ (absentee landowners). The mean proportion of ranching/farming experience was 0.52 $(\mathrm{SD}=0.35 ; \mathrm{MD}=0.50)$, with $12 \%$ of the sample having no experience and $6 \%$ indicating they have been ranching/farming their entire life.

We asked landowners if they had ever spoken with a Natural Resources Conservation Service representative (yes $=48 \%$ ), Texas Parks \& Wildlife biologist (yes $=29 \%$ ), or their county extension agent (yes $=49 \%$ ). Over one-quarter of respondents $(26 \%)$ indicated they had participated in a conservation program (e.g., US Department of Agriculture Conservation Reserve Program) in the past $10 \mathrm{yr}$. Finally, about one half of respondents $(53 \%)$ indicated an intention to participate in the VIP presented in this study (mean $[\mathrm{M}]=4.1 ; \mathrm{SD}=2.3$; $\mathrm{MD}=5$; range $=1-7)$.

Ranching Centrality. On average, respondents identified themselves as ranchers and indicated that farming and ranching plays at least a somewhat important role in their life (see means in Table 1). Respondents were less likely to identify as a farmer; however, during interviews many respondents commented that ranchers are, by necessity, grass farmers. The reliability coefficient for these three items was 0.79 , indicating high internal consistency. Respondents were generally neutral in response to their financial dependence on their land. For 
Table 2. Goodness-of-fit indices of competing models for 252 landowners in central Texas. ${ }^{1}$

\begin{tabular}{lccccccc}
\hline Mediation models & $\chi^{2}$ & $\mathrm{df}$ & SRMR & RMSEA & CFI & AIC & $\Delta$ AIC \\
\hline Full mediation & 128.76 & 61 & 0.048 & 0.067 & 0.963 & 188.759 & - \\
Partial mediation & 128.36 & 60 & 0.048 & 0.067 & 0.963 & 190.363 & -1.60 \\
\hline
\end{tabular}

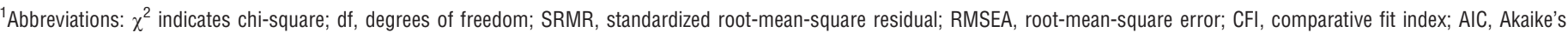
information criterion; $\triangle \mathrm{AIC}$, change in Akaike's information criterion.

most respondents, their place was not an important source of income although many considered their operation to be a business. Financial dependence also exhibited a high level of internal consistency (Cronbach's alpha $=0.87$ ). Finally, respondents generally expressed pride in their land. On average, respondents reported that the land had been in their family for over $40 \mathrm{yr}$, but there was much variation in response $(\mathrm{M}=41.2$; $\mathrm{SD}=37.9 ; \mathrm{MD}=29$; range $=2-173)$. The rootedness items also exhibited high internal consistency (Cronbach's alpha $=0.79$ ). Respondent attitudes toward enrolling were generally positive with means of $4.9(\mathrm{SD}=1.9), 5.2(\mathrm{SD}=1.6)$, and $5.3(\mathrm{SD}=1.3)$ for the respective experiential, instrumental, and overall dimensions. The reliability coefficient for these items was 0.92.

Confirmatory factor analysis supported the conceptualization of centrality as a second-order latent construct comprised of self-identity, financial dependence, and rootedness to the land. The goodness-of-fit indices, which indicate the degree to which the model fits the data, indicated that the model provided a reasonably good fit to the data $\left(\chi_{(24)}^{2}=59.15\right.$; SRMR $=0.04$; RMSEA $=0.08 ; \mathrm{CFI}=0.97)$. Standardized factor loadings were 0.65 or greater, indicating the observed variables were good indicators of the latent constructs. Modification indices indicated that the model fit could not be improved by allowing observed variables to load on a different latent construct. Validity and reliability assessments of the firstand second-order models indicated sufficient levels of construct validity, reliability, and average variance explained. Based on this, we concluded that the lifestyle centrality construct was sufficiently encapsulated using the observed variables.

\section{Mediation Models}

To test the hypothesis that attitude mediates the relationship between centrality and intention to enroll in a VIP, we examined two structural-equation models. First, the partial mediation model allowed for a direct effect between lifestyle centrality and intention (dashed line in Fig. 1). Controlling for attitude, the direct effect of lifestyle centrality on intention to enroll was not statistically significant $(\beta=-0.04, z=-0.64$, $P=0.52$ ). Lifestyle centrality did have a strong effect on intention, but its effect was indirect via attitude $(\beta=-0.19$; $z=-3.76 ; P<0.01)$. This indirect effect was calculated by multiplying the two coefficients $(-0.30 \times 0.62=-0.19)(\mathrm{Ta}-$ bachnick and Fidell 2007). Thus, attitude fully mediates the relationship between lifestyle centrality and intention to enroll. In addition, Table 2 shows that the models were equivalent both statistically $\left(\Delta \chi^{2}=0.4 ; d f=1 ; P=0.53 ; \Delta \mathrm{AIC}=-1.60\right)$ and in model fit (SRMR $=0.05$; RMSEA $=0.07$; CFI $=0.96)$. Based on these results, the full mediation model was preferred and Hypothesis 1 was supported. Lifestyle centrality is not directly related to intention to enroll in a VIP; it is indirectly related to intention through attitude.
As predicted by Hypothesis 2, attitude toward participating decreased as the centrality of farming/ranching to the respondents' lifestyle increased $(\beta=-0.31 ; z=-3.98 ; P<0.01$; $R^{2}=0.09$ ). Finally, Hypothesis 3 was supported-a respondent's intention to participate increased as attitude toward enrolling became more positive $(\beta=0.63 ; z=10.67 ; P<0.01$; $\left.R^{2}=0.40\right)$.

In summary, the relationship between lifestyle centrality and a landowner's intention to enroll in a VIP focusing on endangered species recovery was fully mediated by the attitude a landowner held toward the VIP. The more central ranching or farming was to a landowner's lifestyle, the more negative the individual's attitude toward enrolling in the VIP. The more negative an individual's attitude, the less likely they were to indicate an intention to enroll.

\section{DISCUSSION}

Landowner responses to the general behavioral intentions to enroll in a program to protect wildlife habitat and endangered species habitat serve as a baseline to understand initial reactions to these types of programs in general. About half of the landowners in this sample were at least somewhat willing to enroll in a program focusing on endangered species. A discussion of whether or not this level of interest is high or low requires further research; however, incentives likely are an important tool for enhancing endangered species recovery on working lands. Kreuter et al. (2006), for example, found that landowners in Colorado, Texas, and Utah generally disagreed with the notion that landowners should protect endangered species habitat without compensation from the public. In their study, ranchers in Texas disagreed more strongly with the statement than did those in either Colorado or Utah. Similarly, Raymond and Olive (2008) found that $41 \%$ of landowners responded negatively to the idea that they should bear the costs of endangered species conservation without incentives. Brook et al. (2003, p. 1641) found a positive correlation between landowners who thought they should not "bear financial responsibility" for conservation and those indicating that they managed their properties to minimize the chance of an endangered species occupying it. Although incentives may be an essential tool to promote endangered species recovery on private lands, they are not a panacea. Our findings suggest that achieving private-landowner cooperation for endangered species recovery on private lands using incentive programs may be a greater hurdle on lands where the owner strongly selfidentifies as a rancher or farmer, is dependent on the land for income, and has a strong attachment to their land.

Previous research relating landowner characteristics to cooperation with endangered species recovery focuses almost 
exclusively on demographic analyses. Although myriad demographic factors have been identified as being systematically related to enrollment, including age, education, membership in conservation or forestry organization, interaction with agencies and their personnel, years of ownership, hectares owned, onsite residence, owning vs. leasing land, income derived from land, and so on (Kraft et al. 1996; Nagubadi et al. 1996; Kline et al. 2000; Zhang and Flick 2001; Zhang and Mehmood 2002; Langpap and Wu 2004; Mehmood and Zhang 2005), the generalizations that can be drawn from these studies are limited. In some studies age is important and in others it is not. Interacting with an agency or forester may positively (e.g., Kraft et al. 1996) or negatively (e.g., Nagubadi et al. 1996) influence participation. Some research indicates that fear of government control is a constraint to enrollment (Smith et al. 2007), whereas others claim it is not a factor at all (e.g., Langpap 2004). These mixed outcomes do little to paint a clearer picture of whether landowners intend or do not intend to enroll in specific conservation programs.

Our study adds to this literature by focusing on socialpsychological variables that address a landowner's psychological involvement and commitment to being a full-time owneroperator of a ranching or farming operation. By incorporating self-identity, resource dependence, and sense of place to characterize landowners, we essentially examined a psychological profile of how landowners think about their land. Despite some literature that suggests self-identity is uniquely able to predict behavior beyond that of attitude (Eagly and Chaiken 1993), we found that lifestyle centrality acted as a background variable that helped to explain why landowners hold a particular attitude toward a VIP, but it did not help in directly predicting behavior. This finding supports the idea that landowners can have multiple reasons for owning and operating land, and thus obtain multiple satisfactions from doing so (Bliss and Martin 1989; Koontz 2001; Knight and White 2009). Thus, theory related to understanding landowner behavior can be improved by examining landowner motivations for owning and operating land (Lockeretz 1990).

Our results also provide practical implications for understanding and improving private landowner cooperation in endangered species recovery. Program administrators should take note of the indirect relationship between overt behavior (i.e., enrolling), intention, and landowner characteristics (e.g., lifestyle centrality and demographics) so that they can better predict how their programs and interventions designed to increase participation may actually affect behavior. For example, outreach that relies solely on information provision directed at demographically segmented ranchers and farmers is unlikely to influence behavior except in cases where a rancher or farmer is already motivated to adopt beneficial land management practices but lacks the necessary information to do so (e.g., Schultz 2002). Information is a background variable that, in the right context (see Toman et al. 2006), can affect an individual's belief system but otherwise often serves to simply reinforce existing beliefs (e.g., Reading and Kellert 1993). Consequently, promoters of awareness campaigns that merely provide information based on landowner type should have no expectation of directly affecting behavior. Rather than information provision, social-marketing approaches that segment landowners based on lifestyle centrality while targeting attitudes and beliefs may be more effective (Rothschild 1999; Sorice in press).

Understanding, predicting, and changing landowners' willingness to participate in a VIP for endangered species can be improved in two ways. First, identifying relevant beliefs landowners hold about enrolling provides program administrators with information on which to base an intervention to change attitudes and ultimately enhance participation (Sorice, in press). Demographic factors and lifestyle centrality can be related to the beliefs landowners hold about VIPs. For example, amenity migration theory suggests that landowners who do not depend on agricultural production may have more positive conservation attitudes in general (Gosnell and Abrams 2009) and thus may have more positive beliefs about the outcomes associated with participating.

Second, short of observing actual landowner behavior pertaining to the issue of concern, the best predictors of behavior may be other behavioral items. Focusing on items that are more closely related to the behavior of interest can improve prediction and also provide some practical insight into participation. Sorice and Conner (2010), for example, found positive relationships between enrollment in the same endangered species habitat program assessed in this study and landowner willingness to enroll in both brush control and wildlife-oriented cost-share programs that do not focus on endangered species. Thus, one avenue for improving participation in the endangered species program may be to cooperate with the Natural Resource Conservation Service, for example, to identify landowners on the waiting list for Farm Bill costshare programs that employ the same land-management practices that benefit a target endangered species.

One limitation of this study is that we were only able to measure behavioral intention and not actual behavior. Although from a theoretical point of view intention predicts behavior (Fishbein and Ajzen 1975), a number of factors can intervene. For example, the degree to which an intention remains stable may change over time. Further, the model does not account for feedback from, for example, behavior to attitude. We have confidence in the measure because intentions predict actual behavior well when the target behavior is voluntary in nature and the decision-making process is deliberate rather than based on impulse (Ajzen and Fishbein 1980). Landowners are able to consider the costs and benefits carefully prior to making a decision. A final limitation is that the generalizability of these results is limited because of the program type (cost share), structure (requirements), and management practices (e.g., prescribed burning) that are specific to the case described here.

\section{IMPLICATIONS}

Rangelands are important to Texas, and biodiversity is important to the ecosystem services that rangelands provide to Texans. Thus, preserving species richness offers a number of direct and indirect benefits. Although this idea was codified in the Endangered Species Act of 1973, the implementation of this policy has not markedly improved the recovery of endangered species on private lands.

Given the complex nature of the problem, incentives matter in endangered species recovery and are increasingly advocated 
as a primary tool to aid recovery efforts on private lands (Shogren et al. 1999). The efficacy of VIPs, however, is inherently tied to participation. Understanding who does or does not participate and why is critical to improving endangered species recovery in the United States (Sorice et al. 2011). Our finding that attitude mediates the relationship between intention and lifestyle centrality has important implications. Knowledge about social variables such as attitudes, beliefs, and motivations are needed to understand underlying reasons for participation and nonparticipation in VIPs fully. Landowner motivations are complex; that is, landowners derive multiple satisfactions from their land and have multiple reasons for owning and operating it. Relying on landowner characteristics alone cannot capture these aspects of being a landowner, and subsequent segmentation approaches relying on them will likely be inefficient at best. Program administrators need to be aware of the causal relationships between demographics, beliefs, attitudes, and behaviors in order to design more appealing programs and recruit participants.

\section{ACKNOWLEDGMENTS}

G. Luikart and C. Ratheal assisted with data collection, G. Kyle provided comments on latent variable modeling and statistical programming, and A. Snelgrove provided GIS support.

\section{LITERATURE CITED}

AJZEN, I. 2002. Constructing a TPB questionnaire: conceptual and methodological considerations. Available at: http://www-unix.oit.umass.edu/ aizen/pdf/tpb. measurement.pdf. Accessed 25 October 2006.

AJZEN, I., AND M. FISHBEIN. 1980. Understanding attitudes and predicting social behavior. Englewood Cliffs, NJ, USA: Prentice Hall. 278 p.

AJzen, I., And M. FishbeIN. 2005. The influence of attitudes on behavior. In: D. Albarracín, B. T. Johnson, and M. P. Zanna [EDs.]. The handbook of attitudes. Mahwah, NJ, USA: Erlbaum. p. 173-221.

[AAPOR] American Association for Public Opinion Research. 2006. Standard definitions: final dispositions of case codes and outcome rates for surveys. Lenexa, KS, USA: AAPOR. $48 \mathrm{p}$.

Anders, A. D., and D. C. Dearborn. 2004. Population trends of the endangered golden-cheeked warbler on Fort Hood, Texas, from 1992-2001. Southwestern Naturalist 49:39-47.

ArbuckLE, J. R. 2007. Amos 16.0 user's guide. Springhouse, PA, USA: Amos Development Corporation. $656 \mathrm{p}$.

Bean, M. J. 1998. The endangered species act and private land: four lessons learned from the past quarter century. Environmental Law Reporter 28:10701-10710.

BLISS, J. C., And A. J. MarTin. 1989. Identifying NIPF management motivations with qualitative methods. Forest Science 35:601-622.

Brandenburg, A. M., and M. S. Carroll. 1995. Your place or mine?: the effect of place creation on environmental values and landscape meanings. Society and Natural Resources 8:381-398.

Brook, A., M. Zint, and R. De Young. 2003. Landowners' responses to an Endangered Species Act listing and implications for encouraging conservation. Conservation Biology 17:1638-1649.

Brown, T. A. 2006. Confirmatory factor analysis for applied research. New York, NY, USA: Guilford Press. 475 p.

BuRKe, P. J. 1991. Identity processes and social stress. American Sociological Review 56:836-849.

Cearly-Sanders, J. 2005. Relationships among landowner and land ownership characteristics and participation in conservation programs in central Texas [thesis]. College Station, TX, USA: Texas A\&M University. 88 p.
Dillman, D. A. 2000. Mail and internet surveys: the tailored design method. New York, NY, USA: John Wiley \& Sons, Inc. 464 p.

Eagly, A. H., and S. Chaiken. 1993. The psychology of attitudes. Belmont, CA, USA: Thomson/Wadsworth. $794 \mathrm{p}$.

Fishbein, M., AND I. AJzen. 1975. Belief, attitude, intention, and behavior: an introduction to theory and research. Reading, MA, USA: Addison-Wesley. $578 \mathrm{p}$.

FISHBEIN, M., AND I. AJzen. 2010. Predicting and changing behavior: the reasoned action approach. New York, NY, USA: Psychology Press. 518 p.

Gosnell, H., AND J. Abrams. 2009. Amenity migration: diverse conceptualizations of drivers, socioeconomic dimensions, and emerging challenges. GeoJournal 76:303-322.

Gosnell, H., J. Haggerty, and W. Travis. 2006. Ranchland ownership change in the greater yellowstone ecosystem, 1990-2001: implications for conservation. Society \& Natural Resources 19:743-758.

Hadlock, T. D., and J. A. Beckwith. 2002a. Providing incentives for endangered species recovery. Human Dimensions of Wildlife 7:197-213.

HadLoCk, T. D., AND J. A. BECKWITH. 2002b. Recommendations to improve recovery of endangered species in the United States. Human Dimensions of Wildlife 7:37-53.

HatcheR, L. 1994. A step-by-step approach to using SAS for factor analysis and structural equation modeling. Cary, NC, USA: SAS Institute. 588 p.

Homer, P. M., and L. R. Kahle. 1988. A structural equation test of the valueattitude-behavior hierarchy. Journal of Personality and Social Psychology 54:638-646.

JoNES, J. S. 2006. Development of a decision support geographic information system for land restoration programs in the Leon, Lampasas, and Bosque river watersheds [thesis]. College Station, TX, USA: Texas A\&M University. 198 p.

KLINE, J. D., R. J. ALIG, AND R. L. Johnson. 2000. Forest owner incentives to protect riparian habitat. Ecological Economics 33:29-43.

KnIGHT, R. L., AND C. White [EDS.]. 2009. Conservation for a new generation. Washington, DC, USA: Island Press. $515 \mathrm{p}$.

Koontz, T. M. 2001. Money talks? But to whom? Financial versus nonmonetary motivations in land use decisions. Society \& Natural Resources: An International Journal 14:51-65.

Kraft, S. E., C. Lant, and K. Gillman. 1996. WQIP: an assessment of its chances for acceptance by farmers. Journal of Soil and Water Conservation 51:494-499.

Kreuter, U., M. NaiR, and D. Jackson-Smith. 2006. Property rights orientations and rangeland management practices: Texas, Utah, and Colorado. Rangeland Ecology \& Management 59:632-639.

Kyle, G., J. Absher, W. Norman, W. Hammitt, and L. Jodice. 2007. A modified involvement scale. Leisure Studies 26:399-427.

LangPaP, C. 2004. Conservation incentives programs for endangered species: an analysis of landowner participation. Land Economics 80:375-388.

LANGPAP, C., AND J. Wu. 2004. Voluntary conservation of endangered species: when does no regulatory assurance mean no conservation? Journal of Environmental Economics and Management 47:435-457.

LOCKERETZ, W. 1990. What have we learned about who conserves soil? Journal of Soil and Water Conservation 45:517-521.

Lubowski, R. N., M. Vesterby, S. Bucholtz, A. Baez, and M. J. Roberts. 2006. Major uses of land in the United States, 2002. Washington, DC, USA: US Department of Agriculture. $54 \mathrm{p}$.

Lueck, D., and J. A. Michael. 2003. Preemptive habitat destruction under the endangered species act. Journal of Law and Economics 46:27-60.

Mehmood, S. R., And D. Zhang. 2005. Determinants of forest landowner participation in the endangered species act safe harbor program. Human Dimensions of Wildlife 10:249-257.

Millennium Ecosystem Assessment. 2003. Ecosystems and human well-being. Washington, DC, USA: Island Press. $245 \mathrm{p}$.

Nagubadi, V., K. T. McNamara, W. L. Hoover, and W. L. Mills. 1996. Program participation behavior of nonindustrial forest landowners: a probit analysis. Journal of Agricultural and Applied Economics 28:323-336.

NorRIS, S. 2004. Only 30: a portrait of the endangered species act as a young law. Bioscience 54:288-294.

Parkhurst, G. M., and J. F. Shogren. 2003. Evaluating incentive mechanisms for conserving habitat. Natural Resources Journal 43:1093-1149. 
Peterson, T. R., and C. C. Horton. 1995. Rooted in the soil: how understanding the perspectives of landowners can enhance the management of environmental disputes. Quarterly Journal of Speech 81:139-166.

Polasky, S., and H. Doremus. 1998. When the truth hurts: endangered species policy on private land with imperfect information. Journal of Environmental Economics and Management 35:22-47.

RaYmond, L., AND A. Olive. 2008. Landowner beliefs regarding biodiversity protection on private property: an Indiana case study. Society \& Natural Resources 21:483-497.

Reading, R. P., T. W. Clark, and S. R. Kellert. 1994. Attitudes and knowledge of people living in the greater yellowstone ecosystem. Society \& Natural Resources 7:349-365.

ReAding, R. P., AND S. R. Kellert. 1993. Attitudes toward a proposed reintroduction of black-footed ferrets (Mustela nigripes). Conservation Biology 7:569-580.

RothSCHILD, M. L. 1999. Carrots, sticks, and promises: a conceptual framework for the management of public health and social issue behaviors. The Journal of Marketing 63:24-37.

Ryan, R. L., D. L. Erickson, and R. De Young. 2003. Farmers' motivations for adopting conservation practices along riparian zones in a mid-western agricultural watershed. Journal of Environmental Planning and Management 46:19-37.

SchuLTz, P. W. 2002. Knowledge, information, and household recycling: examining the knowledge-deficit model of behavior change. In: T. Dietz and P. C. Stern [EDS.]. New tools for environmental protection: education, information, and voluntary measures. Washington, DC, USA: National Academy Press. p. $67-82$.

SheRIDAN, T. E. 2007. Embattled ranchers, endangered species, and urban sprawl: the political ecology of the new American west. Annual Review of Anthropology 36:121-138.

Shogren, J. F., J. Tschirhart, T. Anderson, A. W. Ando, S. R. Beissinger, D. Brookshire, G. M. Brown, D. Coursey, R. Innes, S. M. Meyer, and S. Polasky. 1999. Why economics matters for endangered species protection. Conservation Biology 13:1257-1261.
Smith, C. M., J. M. Peterson, and J. C. Leatherman. 2007. Attitudes of great plains producers about best management practices, conservation programs, and water quality. Journal of Soil and Water Conservation 62:97-103.

SORICE, M. G. Retooling the traditional approach to studying the belief-attitude relationship: explaining landowner buy-in to incentive programs. Society and Natural Resources 25(5) (in press). doi:10.1080/08941920.2011.603143

SORICE, M. G. 2008. Understanding participation in wildlife conservation programs on private lands [dissertation]. College Station, TX, USA: Texas A\&M University. $126 \mathrm{p}$.

Sorice, M. G., AND J. R. Conner. 2010. Predicting private landowner intentions to enroll in an incentive program to protect endangered species. Human Dimensions of Wildlife 15:77-89.

Sorice, M. G., W. Haider, J. R. Conner, and R. B. Ditton. 2011. Incentive structure of and private landowner participation in an endangered species conservation program. Conservation Biology 25:587-596.

TABACHNICK, B. G., AND L. S. FidelL. 2007. Using multivariate statistics. Boston, MA, USA: Allyn \& Bacon. $980 \mathrm{p}$.

Thompson, B. H. 2006. Managing the working landscape. In: D. D. Goble, J. M. Scott, and F. W. Davis [EDs.]. The endangered species act at thirty. Volume 1. Washington, DC, USA: Island Press. p. 101-126.

Toman, E., B. Shindler, and M. Brunson. 2006. Fire and fuel management communication strategies: citizen evaluations of agency outreach activities. Society \& Natural Resources 19:321-336.

TuAn, Y. F. 1980. Rootedness versus sense of place. Landscape 24:3-8.

Wilkins, R. N., R. D. Brown, R. J. Conner, J. Engle, C. Gillilland, A. Hays, R. D. Slack, and D. W. SteinBaCh. 2003. Fragmented lands: Changing land ownership in texas. College Station, TX, USA: Texas A\&M University. $12 \mathrm{p}$.

Wilkins, R. N., A. G. Snelgrove, B. C. Fitzsimons, B. M. Stevener, K. L. Skow, R. E. Anderson, and A. M. Dube. 2009. Texas land trends. Available at: http:// texaslandtrends.org/. Accessed 8 May 2009.

Zhang, D., And W. Flick. 2001. Sticks, carrots, and reforestation investment. Land Economics 77:443-456.

Zhang, D., AND S. R. MehmO0D. 2002. Safe harbor for the red-cockaded woodpecker: private forest landowners share their views. Journal of Forestry 100:24-29. 